\title{
Optimisation of the traditional Pacific cupped oyster (Crassostrea gigas Thunberg) culture on the French Atlantic coastline: autumnal fattening in semi-closed ponds
}

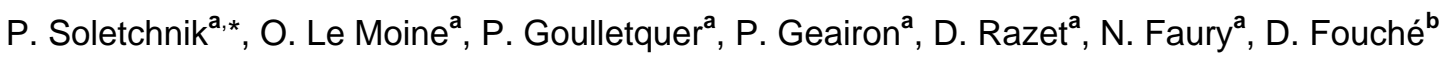 \\ and S. Robert ${ }^{\mathrm{a}}$
}

a Shellfish Research Aquaculture Laboratory of Poitou-Charentes (LCPC), Station IFREMER, Ronce Les Bains, 17390 La Tremblade, BP.133 France

b Direction de l'environnement littoral, Station IFREMER, Ronce Les Bains, 17390 La Tremblade, BP.133 France

*: Corresponding author : Patrick.Soletchnik@ifremer.fr

\begin{abstract}
Oyster farming in France is a traditional activity. Each year, 60,000 tons of C. gigas are fattened before being sold. Present-day fattening techniques for improving oyster taste and colour and increasing the meat weight are not particularly reliable. To optimize the fattening process, large phytoplanktonic blooms were induced in ponds, then distributed in oyster ponds. Despite the variability of the autumn weather conditions, diatoms (Skeletonema costatum) have been successfully cultured in outdoor ponds. During neap tides (when no seawater replenishes the water in the oyster beds), between mid-October and mid-December 1996, the fattening index (the weight of the meat) was constant or increased by $10-15 \%$ when a supplement of algae of 380,000 cells/oyster/day was added to the ponds. Algal supplement was clearly responsible for fattening improvement. In 1995, the addition of 110,000 cells/oyster/day, a significantly lower quantity, was not sufficient to prevent weight loss. Over two periods of 3 months (in 1995 and 1996) of the experiment, a significant reduction in weight (up to 20\%) was observed in oysters grown in ponds which did not receive additional algae.
\end{abstract}

Author Keywords: Marennes Oléron Bay; Oyster farming; Crassostrea gigas; Fattening process 


\section{Introduction}

The Marennes-Oléron Bay (figure 1), with its 100000 metric tonnes stocking biomass of Pacific cupped oysters (Crassostrea gigas) and an annual production of 30000 to 40000 tonnes, is the largest oyster rearing area in Europe. Twenty thousand tonnes of oysters, originating from other French rearing areas completes the oyster stocks, which undergo a fattening process called 'affinage' before commercialisation, therefore representing $40 \%$ of the French production. This fattening process allows the oysters to acquire the taste and often a green colour specific from this rearing area. In 1997, the foreshore of the mainland and the islands off the Charente coast counted 3200 leased hectares. The 3500 ha of semi-closed ponds in the Marennes Oléron Bay account for over $90 \%$ of all French oyster ponds (Deslous-Paoli et al., 1981). The use of salt marshes as "ponds" for "greening" the common European oyster Ostrea edulis dates back to the $17^{\text {th }}$ century (Papy, 1941) and Gaillon (in Moreau, 1970) described the greening technique that was used at the turn of the $19^{\text {th }}$ century. When the common European oyster suddenly disappeared between 1920 and 1921, it was replaced by the Portuguese oyster (Grelon, 1978 The Pacific oyster (Crassostrea gigas) was introduced in massive numbers to France to replace it. Eighty thousand tonnes of this oyster were being produced along the Atlantic coast of France as early as 1976, which indicates how successful the species introduction has been. (Héral, 1989; Grizel and Héral, 1991).

The French traditionally eat oysters during the festive periods and $70 \%$ of commercialised oysters are eaten during the Christmas holidays (SECODIP, 
1999). This is why the fattening period, which lasts between 1 and 2 months (AFNOR, 1985), takes mainly place between October and December. This fattening period is designed to perfect the oyster taste, appearance and colour (Grelon, 1978). Traditionnally, the "spéciales" oysters are first fattened in ponds from May to December at densities of 4-5 oysters per $\mathrm{m}^{2}$. Fattening is then progressively carried out on the foreshore in order to free the oyster ponds for the "fine" oysters. The stocking process called "passée" at 40-50 oysters per m² only lasts for a few weeks. The aim is to modify the taste of the oyster and possibly its colour, since fattened oysters undergo "unpredictable fluctuations in greening" (Grelon, 1978). Many studies have been carried out on Haslea ostrearia, the diatom which is responsible for this greening (Moreau, 1967 ; Neuville and Daste 1970 ; Robert, 1973 ; Robert, 1982; Turpin et al., 1999). Today, oyster ponds are used to produce mainly the "fine" oysters and breeding conditions are governed by the AFNOR norms (1985), which stipulate that oysters must spend one month in these ponds at a breeding density of not more than $1 \mathrm{~kg} / \mathrm{m}^{2}$. Nevertheless, these conditions do not always provide the appropriate quality oyster (Blachier et al., 1998 ; Soletchnik et al., 1998a ; Robert et al., 1998).

Enrichment techniques used in agriculture (e.g., the use of phosphates, lime) have been used to improve the fertility of oyster beds (Deltreil et al., 1977 ; Grelon, 1978 ; Robert et al., 1979b). However the results have often been uneven, making this kind of technique unreliable.

The aim of this study was to test at a commercial level the production of algae using an enrichment technique developed for intensive aquaculture (Baud et al., 1995 ; Hussenot, 1992 ; Gautier et al., 1993 ; Hussenot and Gautier, 1994 ; 
Hussenot et al., 1998), and to measure the effect of a using dietary supplement during the C.gigas fattening in oyster ponds.

\section{Materials and methods}

\subsection{The experimental site}

The experiments were carried out on the Atlantic coast of France in the Marennes-Oléron Bay, in five $450 \mathrm{~m}^{2}$ ponds (figure 1). Seawater flowed in and out of the ponds during the spring tides, under the control of both the lunar cycle (tidal range) and the weather conditions (e.g., wind and atmospheric pressure) (figures 2 and 3). The height of the water column was recorded continuously by using an ecjhosounder probe, therefore allowing a precise estimate of the filling time and seawater volume. This height in the ponds varied between $30 \mathrm{~cm}$ (no seawater inflow) and more than $100 \mathrm{~cm}$ during the "spring tides". It was estimated that in more than $80 \%$ of cases, $50 \%$ and sometimes as much as $70 \%$ of the seawater in the ponds was replaced. The frequency of refilling was around one tide in 3. During "neap tides" as much as one week could pass without any seawater entering the ponds. Depending on the tide strength, the flow of seawater could last anywhere from a few minutes to 2 hours. Oyster ponds 2 and 4 were equipped with a hydraulic ramp which allowed a supplement of phytoplankton to be supplied from associated cultures of algae (figure 2). These ramps ran lengthways across the ponds. Algae were distributed as a continuous flow from each side of a feeding ramp, until algal tank production was empty 


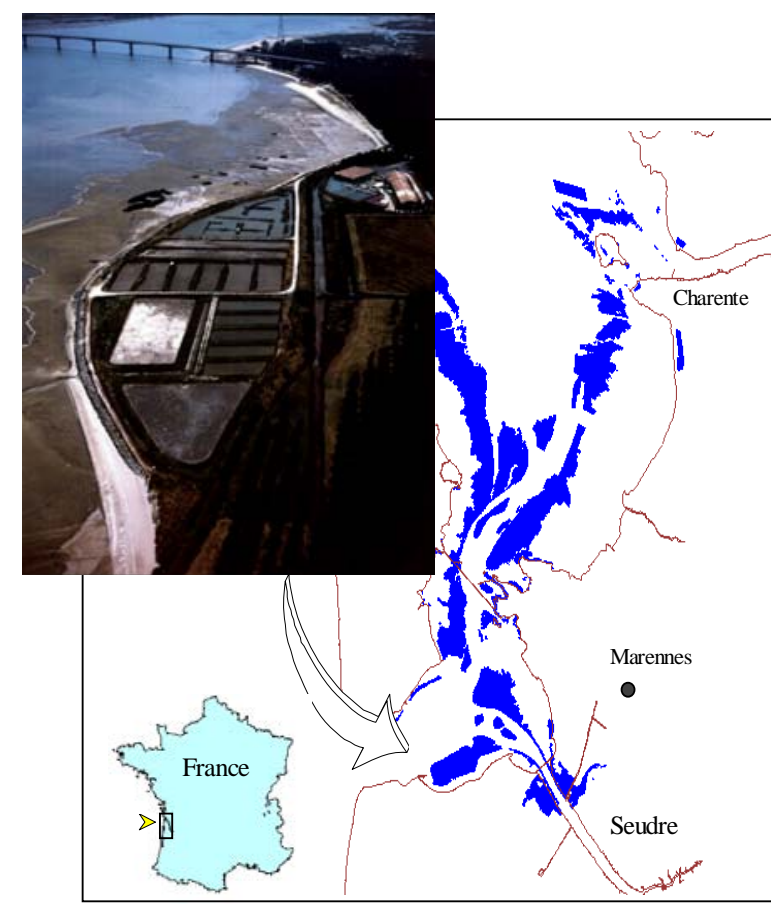

Figure 1. Experimental site located in the southern part of the Marennes Oleron Bay.

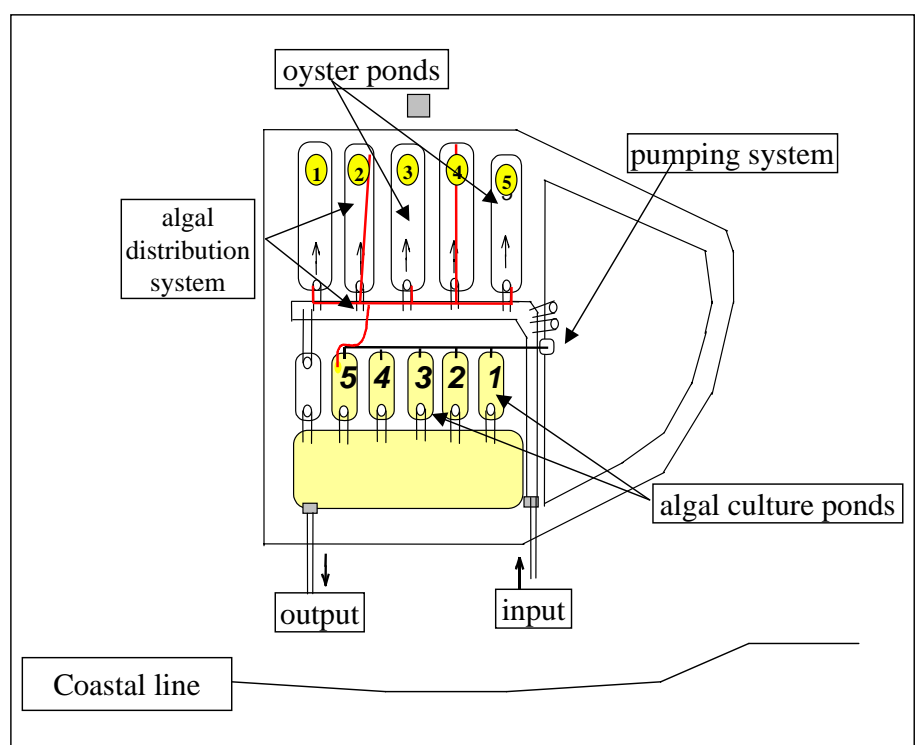

Figure 2. Experimental oyster ponds and phytoplankton production ponds. 


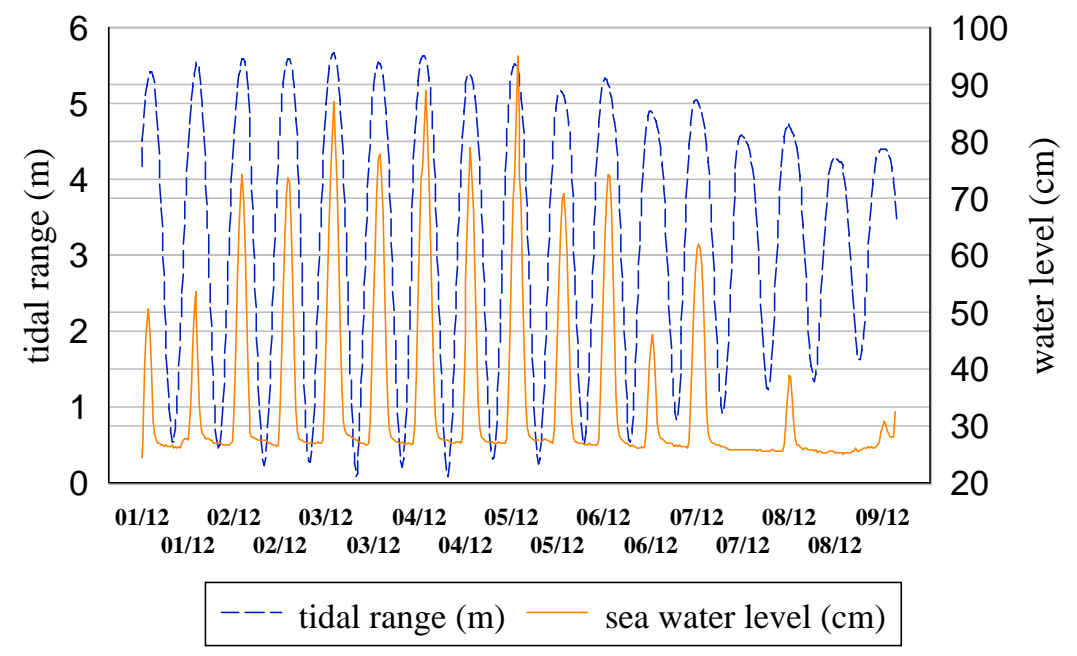

Figure 3. Relationship between the tide cycle and the seawater input into the oyster ponds (e.g. December 1 to 6 spring tide in 1995).

\subsection{Phytoplankton production}

Phytoplankton were produced in clay ponds with a plastic covering of a surface area of $100 \mathrm{~m}^{2}$ and a depth of $70 \mathrm{~cm}$. They were equipped with their own hydraulic system and the seawater supply was pumped in from a reserve pond where sedimentation occurs, therefore limiting the turbidity level (figure 2). In 1995, a "discontinuous" system was used to produce algae. The production pond reached a peak concentration of algae after 5-7 days. The phytoplankton were then distributed within 24 hours in the two algae-supplemented oyster ponds. Seawater was filtered on $200 \mu \mathrm{m}$ bolting gauze filters to avoid any zooplankton predation. In 1996, algal production was carried out using the continuous method (Hussenot and Brossard, 1995). Five ponds were organised in a 5 day-production cycle which provided a continuous supply of phytoplankton to the oyster ponds. The nutrient formula supplied (enrichment) was that established by Hussenot and Brossard (1995) (table 1). The quantities of minerals were sufficient for a 
maximum culture density of around 500000 cells per millilitre. $10^{9}$ cells were added per oyster ; the oysters had an average weight of $\sim 50$ g (Baud et al., 1995 ; Gautier et al., 1993). The phytoplankton cultures were monitored by measuring fluorescence and counting the number of cells each day. Fluorescence was measured with a Turner fluorimetre and cell counts made under the microscope using a Malassez cell counting chamber. The inventory of the main phytoplankton families was also carried out on samples of seawater taken daily from the oyster ponds.

For the purposes of this study, a daily production of $33.5 \mathrm{~m}^{3}$ at 500000 cells per millilitre was necessary. The technique used to initiate the culture was developed by Hussenot and Brossard (1995). The inoculum of algae was natural and came from another culture pond. The culture was "boosted" by diluting and fertilising in the same pond, in accordance with the " continuous" culture technique used by Gautier et al. (1993). Measurements of ammoniacal nitrogen were carried out on a daily basis in each oyster pond using the Koroleff's protocol (Koroleff, 1969).

Table 1. Nutrient supply for a $100 \mathrm{~m}^{3}$ algal culture (from Hussenot and Brossard, 1995)

\begin{tabular}{|c|c|c|c|}
\hline Nutrients & Name & $\begin{array}{l}\text { Daily supply } \\
\text { (for } 100 \mathrm{~m}^{3} \text { ) }\end{array}$ & $\begin{array}{c}\text { Concentration } \\
(\mathrm{mg} / \mathrm{l})\end{array}$ \\
\hline $\mathrm{N}-\mathrm{NH}_{4} \mathrm{Cl}$ & Ammonium chlorid & $808 \mathrm{~g}$ & 150 \\
\hline $\mathrm{P}-\mathrm{PO}_{4}$ & Triphosphate & $240 \mathrm{~g}$ & 15 \\
\hline Silicium & Sodium metasilicate & $1591 \mathrm{~g}$ & 60 \\
\hline $\mathrm{Fe}-\mathrm{FeCl}_{3}$ & Iron chlorid & $41 \mathrm{~g}$ & 3 \\
\hline $\mathrm{Mn}-\mathrm{MnSO}_{4}$ & Manganese sulfate & $27 \mathrm{~g}$ & 1.5 \\
\hline
\end{tabular}




\subsection{The stock of oysters}

The cultured oyster populations used for the 1995 experiment came from Normandy and for the 1996 experiment from the Marennes Oléron Basin (table 2). Oysters were spread out over the bottom of the beds at densities of 20 oysters / $\mathrm{m}^{2}$, which corresponded to a load of $1.0 \mathrm{~kg} \mathrm{~m}^{-2}$ in 1995 and $1.1 \mathrm{~kg} \mathrm{~m}^{-2}$ in 1996. Pond $n^{\circ} 5$ was used as a control of algal production without rearing oysters. Total weight, weight of the shell, wet and dry meat weights were measured on between 30 and 100 oysters sampled during rearing (table 2). The AFNOR quality index is derived from the norm NF V45-056 (1985) and is calculated according to the following equation :

$$
\text { AFNOR }=(\text { wet meat weight } / \text { total weight }) \times 100
$$

An index of between 6.5 and 9 corresponds to "fine" oysters and greater than 9 to "spéciale" oysters. Proximate biochemical composition (i.e., proteins, carbohydrates, glycogen and lipids) were estimated according to the protocols presented by Goulletquer et al. (1988). 
Table 2. Characteristics of the initial oyster conditions and sampling strategy of the Crassostrea gigas oyster population in the semi closed oyster ponds in 1995 and 1996

\begin{tabular}{|c|c|c|}
\hline & 1995 & 1996 \\
\hline Oyster population Origin & Isigny & $\begin{array}{c}\text { Marennes } \\
\text { Oléron Bay }\end{array}$ \\
\hline \multicolumn{3}{|l|}{ Characteristics } \\
\hline Rearing time (days) & 62 & 58 \\
\hline Total weight (g) ( \pm STE) & $47.7 \pm 0.4$ & $56.7 \pm 0.5$ \\
\hline Dry meat weight $(g)( \pm$ STE) & $1.74 \pm 0.011$ & $1.16 \pm 0.014$ \\
\hline AFNOR $(*)$ index $(\%)( \pm$ STE $)$ & $11.91 \pm 0.09$ & $10.92 \pm 0.11$ \\
\hline Rearing density $\left(\mathrm{kg} \mathrm{m}^{-2}\right)$ & 1.0 & 1.1 \\
\hline \multirow{4}{*}{ Sampling time } & $04 / 10 / 95$ & $19 / 10 / 96$ \\
\hline & 18/10/95 & 05/11/96 \\
\hline & 08/11/95 & 25/11/96 \\
\hline & 05/12/95 & $16 / 12 / 96$ \\
\hline
\end{tabular}

* AFNOR : Norme de qualité NFV45-05 (1985).

\subsection{Statistical Analyses}

Analysis of variance were performed for total weight, dry meat weight and AFNOR variables. The least significant difference (LSD test) was then calculated to range means (Cochran and Cox, 1957). Quality index, ratio (\% of dry weight) of proteins, lipids, carbohydrates and glycogen are presented in Box and Whisker plot (median and quartiles) with a 5\% significant level. Since a punctual and limited variability of phytoplankton level was initially observed among ponds, experimental ponds were statistically compared as separate treatments.

All the statistical analyses were carried out using the Statgraphic V. 3.1 software programme. 


\section{Results}

\subsection{Production of algae in ponds}

In 1995, algae were added during the first neap tide in the month of November (figure 4). For the 1996 fattening period, algae were added as early as October 15th. The maximum daily supplement was $35.10^{9}$ cells in 1996 , as compared with only $16.10^{9}$ cells in 1995 . The total number of algae distributed in each pond was $60.10^{9}$ in 1995 and almost $200.10^{9}$ in 1996 . Among the variety of phytoplankton algae identified in the oyster ponds (table 3), the diatom Skeletonema costatum was the most common (98 \%). The second most common species was the pennate diatom Nitzshia sp.

Phytoplankton production is dependant on weather conditions. The temperature varied from $16-18{ }^{\circ} \mathrm{C}$ in mid-October and fell to less than $5{ }^{\circ} \mathrm{C}$ in mid- December (figure $5 \mathrm{~A}$ ). Insolation and radiance similarly declined (figure $5 \mathrm{~B}$ and $\mathrm{C}$ ): insolation fell from 7-9 hours of sunshine per day to just 1 hour, and diurnal radiance fell from 1200 to less than 200 joules $\mathrm{cm}^{-2}$ over the two months of rearing. Furthermore, in November there was an increase in rainfall and desalination at the surface of the production ponds is detrimental to phytoplankton growth. 


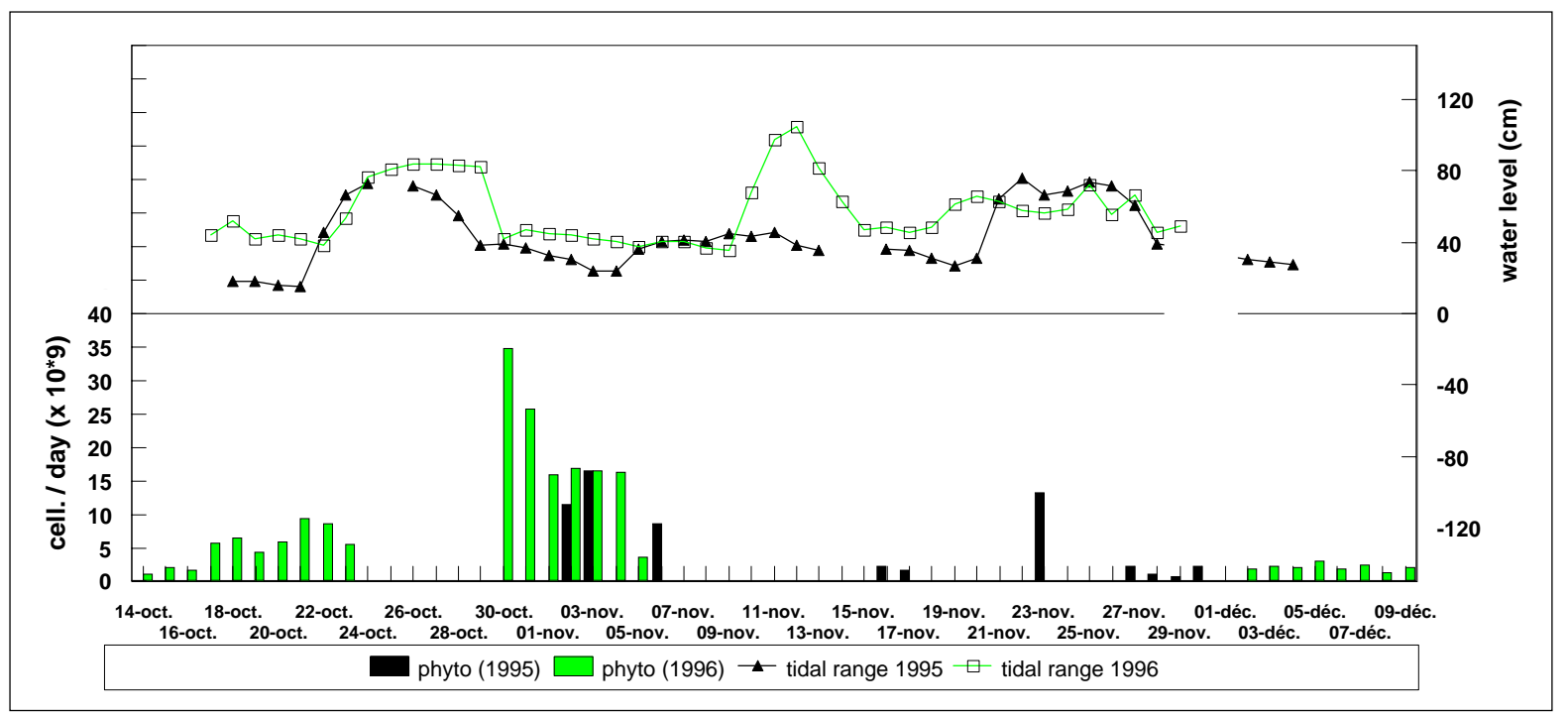

Figure 4. Relationship between the daily phytoplankton production in 1995 and 1996 and the tide cycle directly measured at the pond level. A filling of the oyster ponds occurs when the seawater level is greater than $30 \mathrm{~cm}$.
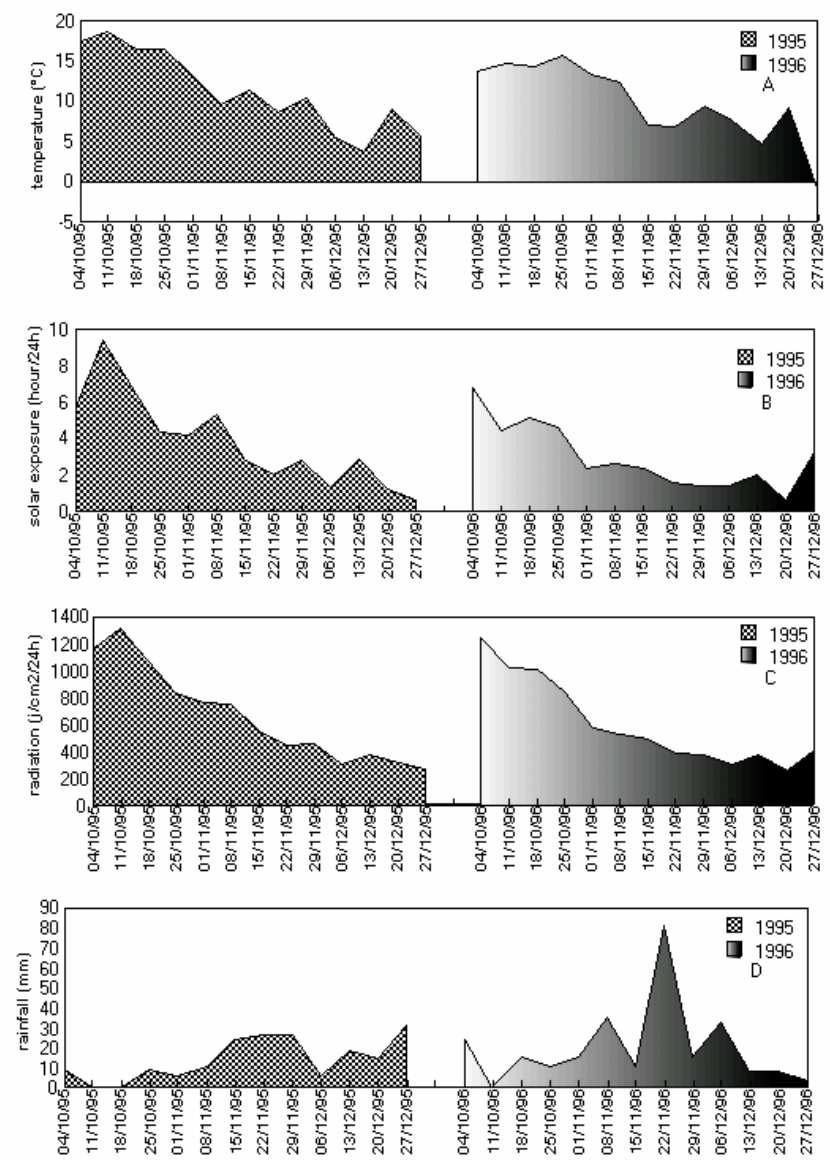

Figure 5. Environmental conditions (1) from October to December in 1995 and 1996. Weekly average air temperature (A), insulation (B), solar energy (C) and cumulative rainfalls (D).

(1) (from Météo - France, 1995, 1996). 
Table 3. Description of the algae abundance (cells/ml) in the oyster ponds at the experiment initiation (Octobre 14, 1996)

\begin{tabular}{llccccc}
\hline Family & $\begin{array}{l}\text { Type - Genus \& } \\
\text { species }\end{array}$ & \multicolumn{5}{c}{ Pond $\left(\mathrm{N}^{\circ}\right)$} \\
\hline & & 1 & 2 & 3 & 4 & 5 \\
\hline Diatoms & Skeletonema & 22600 & 0 & 0 & 360 & 180 \\
& Costatum & & & & & \\
& Central diatoms & 7800 & 20 & 20 & 6700 & 8100 \\
& Pennales diatoms & 300 & 10 & 10 & 110 & 70 \\
& Haslea Ostrearia & 0 & 0 & 0 & 0 & 0 \\
Phytoflagellates & & 180 & 0 & 10 & 6300 & 7200 \\
Dinoflagellates & & 10 & 0 & 0 & 440 & 620 \\
\hline
\end{tabular}

\subsection{Abundance and species composition of the algae in the oyster ponds.}

Within the oyster ponds, the centric diatoms mainly consisted of the genera Chaetoceros, Rhizosolenia, Coscinodiscus, Thallassiosira and Melosira, and the pennate Nitzshia, Thalassionema, Asterionella and Bacillaria. Euglenophyta, Cryptophyta, Rhodomonas sp and Dunaliella sp constituted the principal phytoflagellates. The dinoflagellates were represented by Gymnodynium, Kryptoperidinium, Oxyrrhis and Scripsiella.

When the oyster cultures were set up in mid-October, pond 1 had a naturally high concentration of Skeletonema sp (22600 cells $\mathrm{ml}^{-1}$ ) (table 3). The algal populations showed the same pattern in ponds 4 and 5, with a predominance of centric diatoms and phytoflagellates (6300-8100 cells / ml). Ponds 2 and 3 showed no signs of an algal bloom. However, the limited difference among ponds resulting from one measurement at the initiation of the experiment is negligible compared to the phytoplankton fluxes and algae concentrations which were massively added later on into the ecosystem.

The introduction of oysters at 20 per $\mathrm{m}^{-2}$ (ponds $1,2,3$ and 4 ), together with the addition of algae (ponds 2 and 4), induced significant differences in the algal 
populations present in the ponds (figure 6). From a qualitative point of view, the main families that predominated were the pennates (principally Nitzshia sp.), the phytoflagellates and Skeletonema sp, which were quickly filtered by the oysters. A comparison of the populations of algae in the control pond with those of ponds 1 and 3 clearly shows that the pennates, and in particular Nitzshia sp., were consumed in preference to the phytoflagellates : the concentration of the former dropped by a factor of 40 compared with a factor of only 4 for the latter. The continuous supply of algae modified considerably the chemical equilibrium of ponds 2 and 4. Thus, the concentration of ammoniacal nitrogen in the water column was between $3.0-4.8 \mu \mathrm{mol} \mathrm{l}^{-1}$ for the -supplemented ponds, compared with $0.9-2.8 \mu \mathrm{mol} \mathrm{l}^{-1}$ for the 3 other ponds. Very few Skeletonema sp were found among the plankton in the ponds at the end of the experiment $(<50$ cell $\mathrm{ml} / \mathrm{ml}$ ). Although initially present in abundance, they were consumed in preference to the pennate (Nitzshia sp.) which were present in high concentrations in the water column throughout the experiment (2000-3000 cell ml-1). 

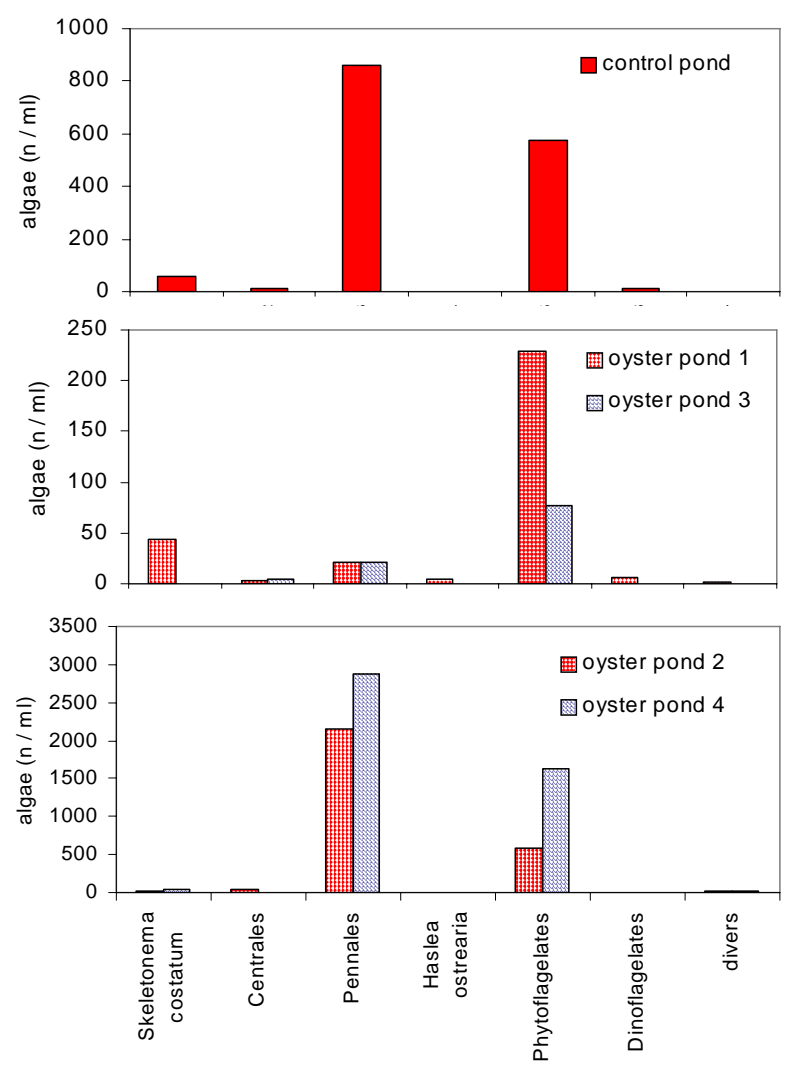

Figure 6. Average abundance of the main phytoplanktonic species during the Crassostrea gigas fattening period in 1996 ; control pond, without oyster ; ponds 2 - 4 and ponds 1 - 3, with- and without algae respectively. The results represent the mean of 9 weekly samples over the experimental time.

\subsection{Growth and quality of oysters}

A comparison of ponds supplemented with algae $(2,4)$ and the others $(1,3)$ shows that the addition of algae had a significant effect on oyster growth (p $<=$ 0.008) and on the AFNOR quality index ( $\mathrm{p}=0.000)$, both in 1995 and 1996 (table 4). Oyster weight increased in all ponds in 1995 and 1996 (table 5). Total weight gain was between 0 and $9 \%$ for the 'traditional' ponds and was as high as $14 \%$ for algae-supplemented ponds. The use of algae as a supplement had a highly significant effect on dry meat weight, which increased by as much as $17 \%$ in pond 4 in 1995 and 1996, and in pond 2 in 1996. For the 'traditional' ponds, dry 
weight loss was between $4 \%$ and $15 \%$ over the two months of culture. In 1995, the AFNOR index fell by 12 to $10.5 \%$ during the first fortnight in October in all of the ponds (figure 7). The dietary supplement in ponds 2 and 4 kept the AFNOR index stable at its original value for pond 4 , when at the same time the loss was close to $20 \%$ for ponds 1 and 3, where the traditional farming method was used (table 5). In 1998, the addition of algae supplement as early as the second fortnight in October prevented the drop in the index that was observed on the 5 of November in ponds 1 and 3. At the end of the culture, the ponds fell into three significantly different "groups" : pond 4, where the index increased by 10 to $15 \%$ and pond 2, where the AFNOR index after two months was identical to the initial value ( 11). Finally, the AFNOR index of the oysters that did not receive a dietary supplement of algae fell by up to $10 \%$ compared with the original value.
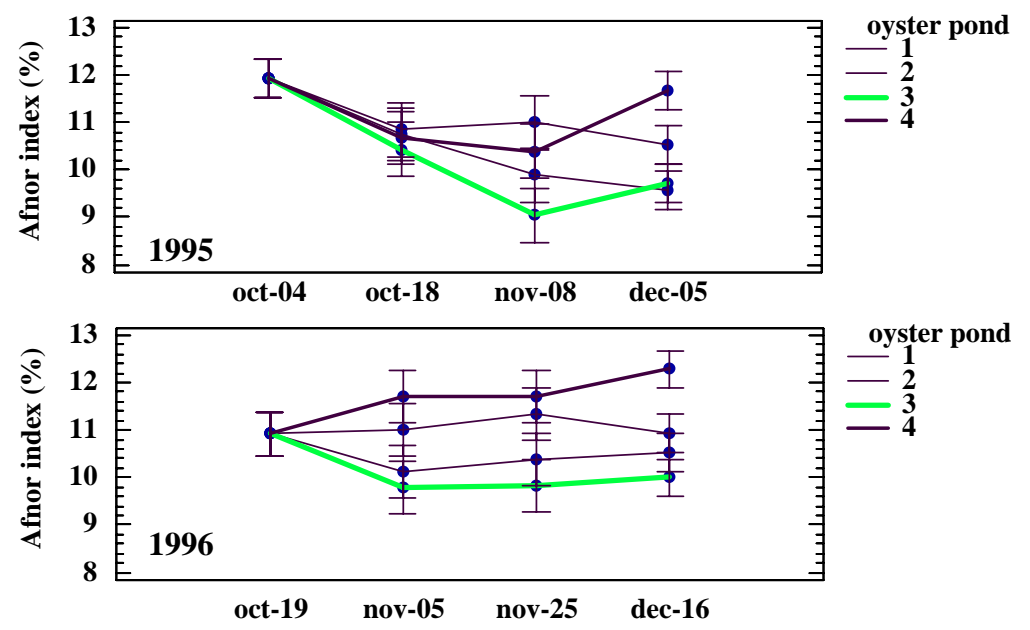

Figure 7. AFNOR index variability (wet meat weight/total weight $x$ 100) of the Pacific cupped oyster (Crassostrea gigas) during the 1995 and 1996 fattening periods. 
Table 4. ANOVA tables of the total weight, dry meat weight and AFNOR index to assess 'Pond' effect on oyster growth in 1995 and 1996.-

\begin{tabular}{llccc}
\hline & $\begin{array}{l}\text { Source of variation } \\
\text { among ponds treatment }\end{array}$ & $\begin{array}{c}\text { Degree of } \\
\text { freedom }\end{array}$ & $\begin{array}{c}\text { F } \\
\text { (Fisher's test) }\end{array}$ & Probability (p) \\
\hline 1995 & Total weight & 3 & 3.99 & 0.008 \\
& Dry Meat weight & 3 & 31.62 & 0.000 \\
\multirow{2}{*}{1996} & AFNOR index & 3 & 21.49 & 0.000 \\
& Total weight & 3 & 8.90 & 0.000 \\
& Dry meat weight & 3 & 20.31 & 0.000 \\
& AFNOR index & 3 & 24.71 & 0.000 \\
\hline
\end{tabular}

Table 5. Growth comparisons between reared populations in food supplemented ponds and non supplemented ponds ( \pm STE). Ponds $\mathrm{N}^{\circ} 2$ and 4 were supplemented by food in contrast to pond $\mathrm{N}^{\circ} 1$ and 3. Significant effect at $1 \%$ olevel ( $\left.<<0.001\right), 1 \%(0.001<\mathrm{p}<0.01), 5 \%(0.01<\mathrm{p}<$ 0.05). * : comparison among ponds.

\begin{tabular}{|c|c|c|c|c|c|c|c|}
\hline 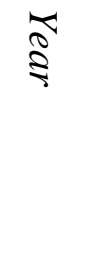 & $\begin{array}{l}0 \\
0 \\
\vdots \\
Z \\
0\end{array}$ & 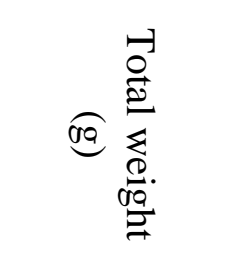 & 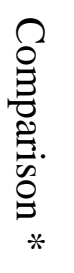 & 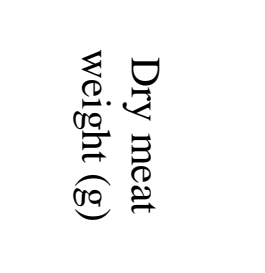 & 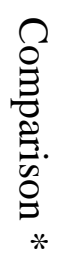 & ف0 & 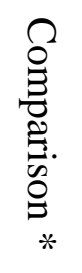 \\
\hline \multirow[t]{4}{*}{1995} & 1 & $49.44 \pm 0.75$ & $\mathrm{~A}$ & $1.52 \pm 0.02$ & $\mathrm{~A}$ & $9.55 \pm 0.19$ & $\mathrm{~A}$ \\
\hline & 3 & $50.72 \pm 0.65$ & A & $1.55 \pm 0.02$ & A & $9.71 \pm 0.19$ & A \\
\hline & 2 & $52.94 \pm 0.78$ & B & $1.68 \pm 0.02$ & $\mathrm{~B}$ & $10.52 \pm 0.23$ & B \\
\hline & 4 & $50.83 \pm 0.70$ & A & $1.80 \pm 0.03$ & $\mathrm{C}$ & $11.67 \pm 0.23$ & $\mathrm{C}$ \\
\hline \multirow[t]{4}{*}{1996} & 1 & $56.77 \pm 0.51$ & $\mathrm{~A}$ & $1.08 \pm 0.02$ & $\mathrm{~A}$ & $10.52 \pm 0.19$ & $\mathrm{AB}$ \\
\hline & 3 & $57.77 \pm 0.51$ & A & $1.03 \pm 0.03$ & A & $9.99 \pm 0.21$ & A \\
\hline & 2 & $60.26 \pm 0.51$ & B & $1.22 \pm 0.03$ & B & $10.93 \pm 0.18$ & $\mathrm{~B}$ \\
\hline & 4 & $59.68 \pm 0.64$ & B & $1.32 \pm 0.03$ & $\mathrm{C}$ & $12.27 \pm 0.19$ & C \\
\hline 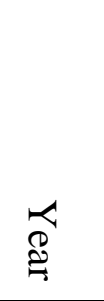 & 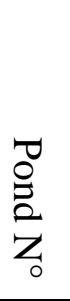 & 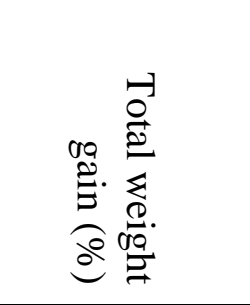 & & 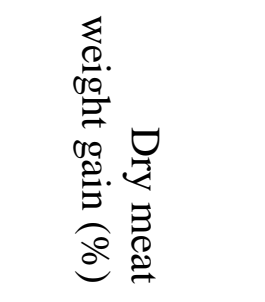 & & 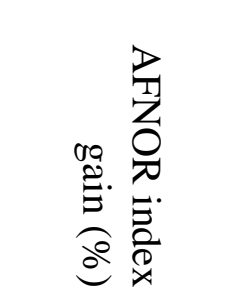 & \\
\hline \multirow[t]{4}{*}{1995} & 1 & $+1.2 /+6.1$ & & $-14.6 /-10.7$ & & $-22.0 /-17.5$ & \\
\hline & 3 & $+4.1 /+9.6$ & & -12.9 / - 9.0 & & - 20.7 / -16.1 & \\
\hline & 2 & $+8.4 /+13.6$ & & $-5.4 /-1.4$ & & - 14.2 / - 8.9 & \\
\hline & 4 & $+4.2 /+8.9$ & & $+1.4 /+5.5$ & & $-4.7 /+0.8$ & \\
\hline \multirow[t]{4}{*}{1996} & 1 & $-1.6 /+1.9$ & & $-9.8 /-3.9$ & & $-6.1 /-0.8$ & \\
\hline & 3 & $+0.1 /+3.7$ & & - $14.1 /$ - 8.3 & & $-11.1 /-5.6$ & \\
\hline & 2 & $+4.5 /+8.1$ & & $+2.1 /+8.3$ & & $-2.3 /+2.9$ & \\
\hline & 4 & $+3.2 /+7.3$ & & $+10.7 /+17.0$ & & $+9.8 /+15.4$ & \\
\hline
\end{tabular}




\subsection{Proximate biochemical composition}

The proximate biochemical composition of the oysters reared in the algaesupplemented and the regular ponds were estimated from November $5^{\text {th }}$ until December $16^{\text {th }}$ 1996. Proteins' and lipids' concentrations ranged between 32.1$34.7 \%$ and $9.2-9.9 \%$ of dry meat weight respectively. Significant differences were observed among ponds at $1 \%$ and $1 \%$ level for carbohydrates and glycogen respectively (Kruskal and Wallis test) (table 6, figure 8). Therefore, the algae supplement allowed a 2-3\% increase of the glycogen concentration. The ratio glycogen/total carbohydrates reached 85-90\% in ponds 1 and 3 (without added food) while a 93-97\% concentration was obtained when supplemented food was provided.

Table 6. Proximate biochemical analysis of the Crassostrea gigas oyster dry meat $(\%)$, fattened in ponds supplemented by algae $(2,4)$ and without supplement $(1,3)$ in 1996.

\begin{tabular}{|c|c|c|c|c|c|}
\hline Pond $\mathrm{N}^{\circ}$ & 1 & 2 & 3 & 4 & $\mathrm{p}(1)$ \\
\hline Proteins (\%) & 34.76 & 32.07 & 34.55 & 32.55 & 0.068 \\
\hline Lipids (\%) & 9.90 & 9.16 & 9.52 & 9.72 & 0.343 \\
\hline Carbohydrates (\%) & 11.36 & 14.24 & 12.66 & 13.38 & 0.005 \\
\hline Glycogen (\%) & 10.18 & 13.31 & 10.71 & 13.00 & $\mathrm{p}<0.000$ \\
\hline
\end{tabular}



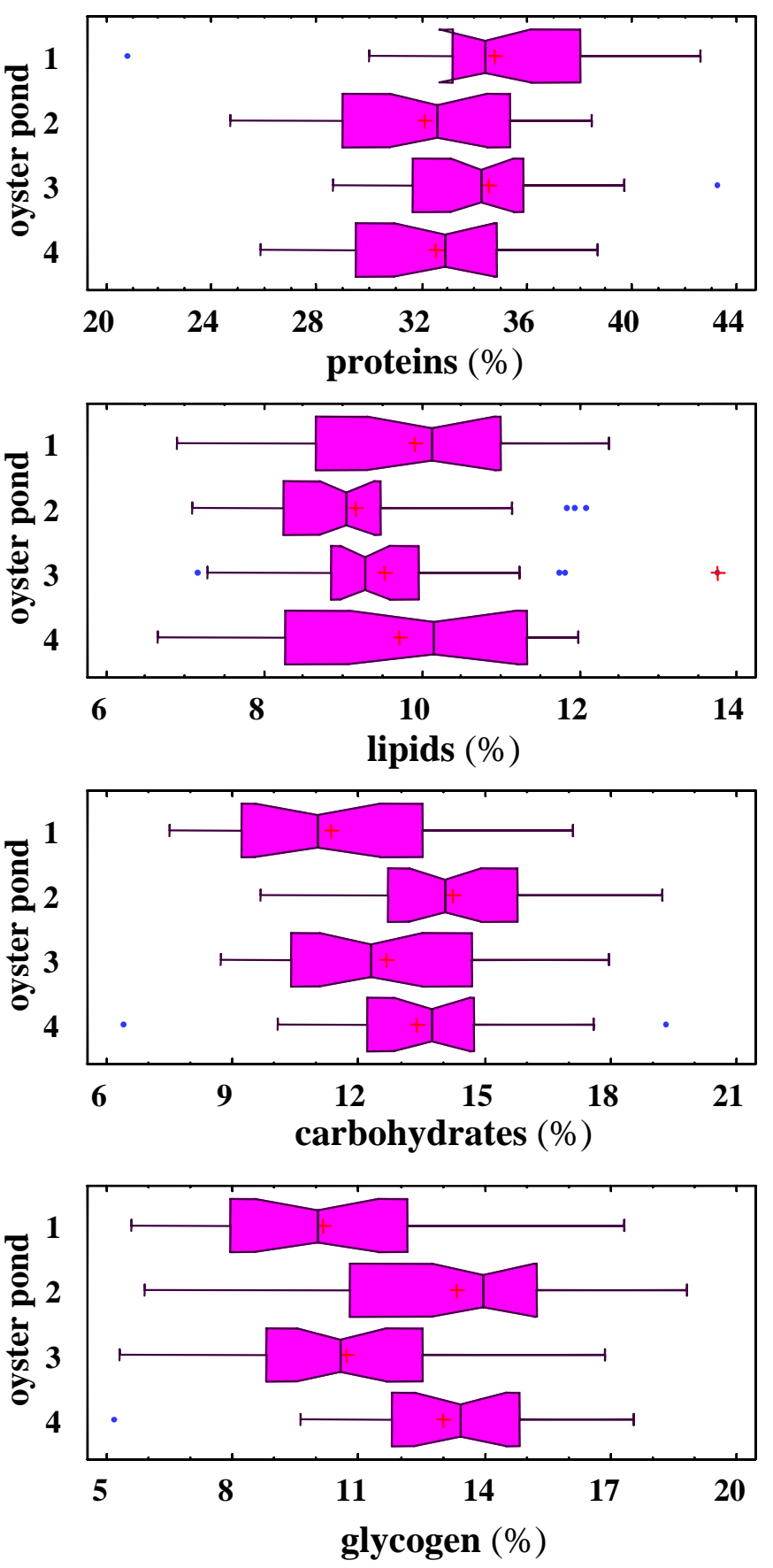

Figure 8. Crassostrea gigas oyster dry meat concentrations of proteins (1), lipids (2), carbohydrates (3) and glycogen (4) (\% of dry meat weight). Oysters reared in algae supplemented ponds $(2,4)$ and without added food $(1,3)$. Quartile dispersion around the median value. 


\section{Discussion}

\subsection{Primary production}

Suspended matter in the ponds rapidly sediments and light can penetrate the water column more easily than in the bay. If the supply of nutrients is sufficient, phytoplankton blooms can develop when light is a limiting factor on the foreshore (Soletchnik et al., 1998b). This explains why an algal bloom could occur in December 1996 in the experimental ponds when the radiance and the temperature were low. A chlorophyll concentration of $20 \mu \mathrm{g} \mathrm{l}^{-1}$ was also observed in a similar ecosystem in December 1982 (Goulletquer et al., 1988).

The meteorological conditions were similar in the autumn of 1995 and 1996. The production of algae was 2.5 times greater in 1996, resulting from the use of the 'continuous' method of culture. Phytoplankton were added during the 'neap tides', when no seawater replenishes the ponds. The temperature and insolation conditions were sufficient to allow a significant production of algae from midOctober to mid-November. The succession of low pressure systems in November and the low temperatures in December resulted in a disappearance of blooms in the open-air ponds, despite an enrichment of the culture medium with iron (Hussenot and Gautier, 1994 ; Hussenot et al., 1998).

Oysters produce nitrogen waste by excretion and certain species of phytoplankton, such as the diatom Nitzshia sp., are better able to metabolise nitrogen in an organic rather than a mineral form (Robert et al., 1979a; Robert et al., 1981; Maestrini and Robert, 1981; Vincendeau, 1987). The diatom responsible for greening fattened oysters, Haslea ostrearia, is also an opportunistic species 
whose development is associated with the decline of algal blooms, and in particular with the disappearance of chlorophyll $a$ and $c$ (Moreau, 1970). This author defined greening as an ecological phenomenon of disrupted metabolism that alternates with the development of flora within the oyster pond. More recently, several studies have refined our knowledge of this species and attempted to control its production (Robert, 1982; Turpin et al., 1998). Concerning the cultures set up in the autumn of 1995 and 1996, the flora biodiversity found in the ponds was limiting the 'greening' process targeted by the oyster farmers.

A study of the algal populations and a comparison of the different ponds confirmed that $C$. gigas carries out a selection on the organic matter in suspension in the natural environment (Riera and Richard, 1996), and between the different families of algae (Bougrier et al., 1997). In the context of this study, the diatom Skeletonema costatum was consumed in preference to the pennate Nitzshia sp., whereas the oysters avoided the phytoflagellates.

\subsection{Growth and quality of the cultured oysters}

In the 70's, during the fattening period, oysters were cultured at 3-4 oysters $\mathrm{m}^{-2}$ (Deslous-Paoli et al., 1981 ; Zanette and Garnier, 1981). When the AFNOR norm was introduced in 1985 for the 'fines de claires', a one month fattening period at a ma ximal density of 20 C. gigas per $\mathrm{m}^{2}$ was authorised. This density is commonly used by oyster farmers on their farms. In the autumn of 1996, there was a daily gain in dry weight during fattening on traditional farms of between 1.1 and $2.1 \mathrm{mg} \mathrm{day}^{-1}$ within the intertidal area in the south of the Marennes Oléron Bay (growth monitoring network data from the LCPC). However weight loss was observed in oyster ponds (between 1.4 and 2.2 mg day ${ }^{-}$ 
$\left.{ }^{1}\right)$. In 1996, the climatic and hydrological conditions facilitated oyster growth rates within the intertidal area, and mainly in the southern part of the bay. Nevertheless, for almost 10 years oysters grown in the 6 stations spread out over the Marennes Oléron Basin (LCPC growth network) have often shown a significant loss of dry weight during the autumn (Le Moine et al., 2000). This result is in agreement with those of Deslous-Paoli and Héral (1988) who reported negative growth of C.gigas in October in the Marennes Oléron Bay. This period was marked by a temperature decline and a shortening of the photoperiod. Although the oyster has adapted well to the French coast, the fact remains that it is an exotic species in terms of its development (phylogenesis) and its biological cycle means that it passes through a period of relative fragility in summer and autumn (Soletchnik et al., 1997). The concentration of oyster leasing grounds in the Marennes Oléron Basin, and in particular in the south (Soletchnik et al., in press), induces a biomass overstocking problem, reducing the trophic resources available for the renewed period of growth after the spawning in summer. Primary production is low during this period. The 'biological' advantages of deploying oysters in oyster ponds during this period are somewhat irregular and are mainly associated with the penetration of sunlight into the water column. However, this advantage is limited since the photoperiod is decreasing over time in the autumn. The absence of food for 8-10 days in a row during the neap tides constitutes the main constraint of placing the oyster stocks in ponds. In the situation where a choice must be made between rearing in the autumn on the foreshore or in oyster ponds, the conditions of climate, with their annual variations, must be weighed against primary production, which is low in the autumn but is higher in ponds than on the foreshore. By contrast, during this period a significant part of the 
resource of nutrients accessible to oysters comes from organic matter that was deposited on the foreshore or at the bottom of the oyster ponds and is then resuspended. This organic matter derives from detritus, living organisms and byproducts of oyster biodeposits (Deslous-Paoli, 1980; Sornin et al., 1987; Cariou and Blanchard, 1994). Turbulence is much greater along the foreshore than in the oyster ponds. This turbulence comes from tidal currents, the lapping of the waves and the shearing effect (direct erosion) caused by the wind. In oyster ponds, the food supply is resuspended through hydrodynamic action, over a period which is limited to a few hours a week. The wind plays the most important role in this process and is probably the main factor responsible for fattening quality in oyster beds.

Using the conditions defined by the 'spéciale de claire' norm for fattening (10 oysters per $\mathrm{m}^{2}$ for 1 month), C. gigas dry weight fell by between 0 and $25 \%$ between 1990 and 1994 (Blachier et al., 1998). Using the farming conditions for 'fine de claire' (20 oysters per $\mathrm{m}^{2}$ for 2 months), the loss of dry weight was between $4 \%$ and $15 \%$. These results show that density is not the only critical factor for fattening C.gigas in oyster ponds. Differences in density of between 2.5 and 10 oysters $\mathrm{m}^{-2}$, using traditional conditions of fattening, did not result in any differences in growth (Soletchnik et al., 1995). A similar result was obtained in 1995, when a density of 40 oysters $\mathrm{m}^{-2}$ was compared to a density of 20 oysters $\mathrm{m}^{-2}$. Robert et al. (1998) came to the same conclusions with densities of 10, 20 and 30 oysters per $\mathrm{m}^{2}$. Thus, even if densities in the beds are increased, this factor should not be considered without additional factors such as meteorological data in 'fattening' oysters. 
By contrast, the effect of the dietary supplement, which was 2.5 times greater than in 1996 compared with 1995 and which was seen earlier in 1996, was directly related to the fattening index (AFNOR) at the end of maturation. The importance of this supplement, compared with the results obtained in the control oyster ponds, would appear to provide a clear explanation for the improved growth rates achieved at the end of fattening process. This relationship between the quantity of algae found at the outlet of the culture pond and the end product of autumn fattening is one of the only cause and effect relationships established during this process. The second concerns an experiment carried out in 1994, when it was shown that currents dependent on the prevailing winds concentrated particulate matter in those sectors where oyster growth rate was significantly greater (Soletchnik et al., 1995).

In general, the fattening index at the end of the process will depend on the initial quality of the stock (Blachier et al., 1998 ; Robert et al., 1998). Thus, with an initial AFNOR condition index of 11-12, oysters end up with a repletion index greater than 9 and fulfill the requirements of the 'Spéciale de claire' norm. This becomes more difficult to achieve if the initial index is below 10 .

\subsection{Variability of the fattening results}

Although the variability among different geographical 'pond' sectors of the Marennes Oléron bay is high (Blachier et al., 1998), this is also true for oyster ponds within the same experimental structure. In 1995 and in 1996, oysters conditioned in pond 2 grew significantly less than those in pond 4, despite the fact 
that the former were exposed to the same experimental conditions. Similarly, the algal populations were different in the four ponds at the time when the zootechnical test was set up. Thus each pond, within the same geographical area, behaves like an individual mesocosm due to sediment characteristics. This extensive 'behavioural heterogeneity' in this type of ecosystem can also be seen in the greening process. When an oyster bed is divided into several sectors, Haslea ostrearia often only colonises selected ones (Grelon, 1978).

\section{Conclusion}

The technical know-how required for the oyster fattening process is not yet sufficiently advanced to control and reduce the variability in the quality of the end product of oyster farming, which is subject to variations in climate and the environmental pond characteristics. The comparison made between growth rates during the autumn period in ponds or on the foreshore showed that meteorological conditions are critical factors. Thus, a full tide followed by a sunny period can be sufficient to allow algal blooms to develop in December in the ponds but not on the foreshore. By contrast, phytoplanktonic blooms can still occur on the foreshore in October. Although several research programs have been carried out, on Haslea ostrearia, greening in oyster farms remains a 'haphazard' operation (Turpin, 1999). Maintaining or even improving the quality of fattening during the autumn is likely to require increased food availability by either resuspending phytobenthic species or/and providing additional phytoplankton. For the first approach, mechanical systems are expensive but rearing practices where burrowing crustaceans (e.g. shrimp Peneaus japonicus) are combined with oysters 
have given interesting results. Meanwhile, our study demonstrated clearly that an algae dietary supplement continuously distributed during neap tides, was undoubtedly responsible for improving the oyster dry meat weight (fattening level) of the stock in the ponds. Therefore, the technical and biological feasibility of this second approach was clearly demonstrated. However, the extra cost of providing the cultures of algae, which has not been calculated in this study, clearly needs further improvements to be used by professional farmers. Whatever the case, it should be emphasized that the results of the fattening process are strongly correlated with the initial quality of the product.

In the near future, product tracability will likely be required as well as a certification of the technical processes. Based on our results, it appears that the studied parameters are unable to guarantee the occurence of the fattening process within ponds. Therefore, to address that matter, additional parameters to current biometrics, and proximate biochemical composition will be considered including biomarkers, such as polyunsaturated isoprenoid alkenes, aroma as well as fatty acids composition (Belt et al., 1996; Le Guen et al., 2000; Piveteau et al., 1999).

\section{Acknowledgements}

The Regional Poitou-Charentes Council for financing this research program within the pluriannual plan ‘Contrat de plan’ signed with IFREMER (1994-1998) and entitled 'Development of the Oyster Ponds'. The Shellfish Farmer's organization (SRC Marennes Oleron) for sustaining the research effort. 


\section{References}

AFNOR, 1985. Norme française huîtres creuses. Dénomination et classification. NF V 45-056, 5 pp.

Baud, J.P., Brisset, E., Cardinal, M., 1995. Affinage contrôlé en bassin de l'huître creuse Crassostrea gigas. IFREMER, RIDRV-95-17, 35 pp.

Belt, S.T., Cooke, D.A., Robert, J.M., Rowland, S.J., 1996. Structural characterisation of widespread polyunsaturated isoprenoid biomarkers: $\mathrm{A}_{25}$ triene, tetraene and pentaene from the diatom Haslea ostrearia Simonsen. Tetrahedron Letters, 37:4755-4758.

Blachier, P., Carton, B., Guilbaud, Y., Huet, T., Machefaux, L., Oudot, G., Prenveille, C., Zanette, Y., 1998. Affinage de l'huître creuse (Crassostrea gigas) en marais maritimes : bilan de quatre années d'expérimentation au Creaa (Centre Régional d'Expérimentation et d'Application Aquacole). In: Hussenot J., Buchet V. (eds), Marais maritimes et aquaculture. Actes colloq. Ifremer 19, Brest: 79-88.

Bougrier, S., Hawkins, A.J.S., Héral, M., 1997. Preingestive selection of different microalgal mixtures in Crassostrea gigas and Mytilus edulis, analysed by flow cytometry. Aquaculture 150, 123-134.

Cariou, V., Blanchard, G., 1994. Caractérisation et quantification pigmentaire du microphytobenthos d'une vasière intertidale : résultats préliminaires. J. Rech. Oceanogr. 19, 173-182.

Cochran, W.G., Cox, G.M., 1957. Experimental designs. Eds. Wiley and sons. 611 pp

Deltreil, J.P., Feuillet, M., Archambeau, G., 1977. Etude expérimentale de la fertilisation phosphatée dans les claires à huîtres. Rev. Trav. Inst. Pêches marit. 
41, 283-297.

Deslous-Paoli, J.M., 1980. Contribution à l'étude de la biologie de l'huître creuse Crassostrea gigas (Thunberg) dans le bassin de Marennes-Oléron. Thèse de doctorat de troisième cycle. Université d'Aix Marseille, 120 pp.

Deslous-Paoli, J.M., Zanette, Y., Héral, M., 1981. Amélioration de la forme et de la qualité de l'huître Crassostrea gigas Thunberg dans les claires à huîtres de Marennes Oléron. Rev. Trav. Inst. Pêches marit. 45, 181-194.

Deslous-Paoli, J.M., Héral, M., 1988. Biochemical composition and energy value of Crassostrea gigas (Thunberg) cultured in the bay of Marennes-Oleron. Aquat. Liv. Res. 1, 239-249.

Gautier, D., Ledu, C., Hussenot, J., Gérard, A., 1993. Production en masse de Skeletonema costatum en bassins extérieurs par fertilisation minérale: Etude d'un cycle estival. IFREMER, RIDRV-93.033-RA / CREMA-L'Houmeau / La Tremblade, 35 pp.

Goulletquer, P., Nedhif, M., Héral, M., 1988. Production de Palourdes Japonaises Ruditapes philippinarum (Adams et Reeve) en bassin semi fermé: Approche énergétique et relations trophiques. Aquaculture 74, 331-348.

Grelon, M., 1978. Saintonge, pays des huîtres vertes. La Rochelle. Eds. Rupella. 364 pp.

Grizel, H., Héral, M., 1991. Introduction into France of the Japanese oyster Crassostrea gigas. J. Cons. Int. Explor. Mer 47, 399-403.

Héral, M., 1989. Traditional oyster culture in France. In: Barnabé, (Eds), Aquaculture, vol 1. (TEC \& DOC) pp. 342-387.

Hussenot, J., 1992. Maîtriser la stimulation de la productivité naturelle permet de proposer une aquaculture marine semi-extensive dans les marais de la côte 
atlantique française. Aquarevue 41, 31-33.

Hussenot, J., Gautier, D., 1994. Techniques d'utilisation de la silice pour la production en masse des algues diatomées. Synthèse des travaux 1989-1993. IFREMER, RIDRV-94.03-RA / CREMA-L'Houmeau, 26 pp.

Hussenot, J., Brossard, N., 1995. Premiers essais automnaux de culture de diatomées en masse $\left(24 \mathrm{~m}^{3}\right)$ sur eau de mer fertilisée (N/P/Si). Culture sans ensemencement et conditions limitantes. IFREMER, RIDRV-95.02-RA / CREMA-L'Houmeau, 54 pp.

Hussenot, J., Brossard, N., Lefebvre, S., 1998. Mise au point d'un enrichissement de l'eau de mer pour produire en masse des microalgues diatomées comme fourrage pour les huîtres affinées ou stockées en claires. In: Hussenot J., Buchet V. (Eds), Marais maritimes et aquaculture. Actes colloq. Ifremer 19, Brest, 107-115.

Koroleff, F., 1969. Direct determination of ammoniac in natural waters as indophenol blue. CI.E.M., C2, 19, 22p.

Le Guen, S., Prost, C., Demaimay, M., 2000. Application of three aroma extraction techniques for the screening of impact odorants in cooked mussels Mytilus edulis. WAS, EAS Special Publication N²8, p. 383.

Le Moine, O., Geairon, P., Soletchnik, P., Faury, N., Goulletquer, P., Robert, S., Razet, D., Heurtebise, S., Taillade, S., 2000. Réseau de surveillance de la croissance et de la production de l'huître creuse Crassostrea gigas dans le bassin de Marennes Oléron: bilan de 12 années de suivi (1986-1998). IFREMER, DIR/RST/2000/02, 46p.

Maestrini, S.Y., Robert, J.M., 1981. Rendements d'utilisation des sels nutritifs et variation de l'état des cellules de trois diatomées des claires à huîtres de Vendée. Oceanol. Acta 4, 13-21. 
Météorologie Nationale, 1995, 1996. Bulletins climatiques mensuels, pp 25.

Moreau, J., 1967. Recherches préliminaires sur le verdissement en claires : l'évolution de leurs divers pigments liée au complexe pigmentaire de Navicula ostrearia Bory. Rev. Trav. Inst. Pêches marit. 31, 373-382.

Moreau, J., 1970. Le Bassin de Marennes Oléron et l'importance des claires à huîtres. Rev. Trav. Inst. Pêches marit. 34, 383-462.

Neuville, D., Daste, P., 1970. Premières observations concernant la culture unialgale de souches de diatomées provenant de claires ostréicoles de l'Ile d'Oléron. C. R Acad. Sci., Paris 270, 2486-2488.

Papy, H., 1941. La côte atlantique de la Loire à la Gironde. Tome 1 : Les aspects naturels. Introduction à une étude de géographie humaine. Tome 2 : L'homme et la mer. Etude de géographie humaine. Bordeaux. Eds. Delmas, 302 pp et 528 pp.

Piveteau, F., Gandemer, G., Baud, J.P., Demaimay, M., 1999. Changes in lipid and fatty acid compositions of European oysters fattened with Skeletonema costatum diatom for six weeks in ponds. Aquaculture International 7, 341-355.

Riera, P., Richard, P., 1996. Isotopic determination of food sources of Crassostrea gigas along a gradient in the estuarine bay of Marennes - Oléron. Estuar. Coast. Shelf. Sci. 42, 347-360.

Robert, J.M., 1973. La diatomée Navicula ostrearia Bory en baie de Bourgneuf. Rev. Trav. Inst. Pêches marit. 37, 363-368.

Robert, J.M., 1982. Fertilité des eaux des claires ostréicoles et verdissement : Utilisation de l'azote par les diatomées dominantes. Thèse de doctorat d'Etat. Université de Nantes, 281 pp.

Robert, J.M., Maestrini, S.Y., Bagès, M., Dréno, J.P., 1979a. Estimation aux moyens de tests biologiques, de la fertilité pour trois diatomées des eaux des claires à 
huîtres de Vendée. Oceanologica Acta 2, 275-286.

Robert, J.M., Maestrini, S.Y., Héral, M., Rincé, Y., Dreno, J.P., Beker, L., 1979b. Enrichissement expérimental d'eaux printanières de claires à huîtres en baie de Bourgneuf (Vendée, France) : augmentation de la biomasse et utilisation des éléments nutritifs par les algues unicellulaires. Hydrobiologia 96, 53-63.

Robert, J.M., Maestrini, S.Y., Héral, M., Zanette, Y., 1981. Production des microalgues des claires ostréicoles en relation avec l'azote organique dissous excrété par les huîtres. Oceanologica acta, Proceedings of the International Symposium on coastal lagoons, UNESCO, Bordeaux, 8-14 September 1981, 389395.

Robert, S., Goulletquer, P., Soletchnik, P., Geairon, P., Le Moine, O., Razet, D., Faury, N., Taillade, S., 1998. Affinage des huîtres creuses Crassostrea gigas en claires ostréicoles du Bassin de Marennes Oléron : étude des modifications de la Norme AFNOR-NF V 45 056. IFREMER, RIDRV-98.15-RA / La Tremblade, 36 pp.

SECODIP, 1999. Statistiques de productions et de consommations en France. Bulletin annuel 1998, 25p.

Soletchnik, P., Razet, D., Goulletquer, P., Geairon, P., Le Moine, O., Faury, N., 1995. Analyse de la capacité trophique de l'écosystème "claires ostréicoles" dans le cadre de l'affinage de l'huître creuse Crassostrea gigas (Bassin de MarennesOléron). IFREMER, RIDRV-95.24-RA / La Tremblade, 43 pp.

Soletchnik P., Razet, D., Geairon, P., Faury, N., Goulletquer, P., 1997. Ecophysiologie de la maturation sexuelle et de la ponte de l'huître creuse Crassostrea gigas: réponses métaboliques (respiration) et alimentaires (filtration, absorption) en fonction des différents stades de maturation. Aquat. Living Resour. 
10(3), 177-185.

Soletchnik, P., Razet, D., Goulletquer, P., Geairon, P., Le Moine, O., Faury, N., 1998a. Relation entre la capacité trophique de l'écosystème "claires ostréicoles" (Bassin de Marennes Oléron) et la production de l'huître creuse Crassostrea gigas en période d'affinage. In: Hussenot J., Buchet V. (Eds), Marais maritimes et aquaculture. Actes colloq. Ifremer 19, Brest, 89-96.

Soletchnik, P., Faury, N., Razet, D., Goulletquer, P., 1998b. Hydrobiology of the Marennes-Oléron bay. Seasonal indices and analysis of trends from 1978 to 1995. Hydrobiologia 386, 131-146.

Sornin, J.M., Delmas, D., Deslous-Paoli, J.M., 1987. Evolutions quantitatives et qualitatives du seston dans une claire à huîtres. Relation avec la sédimentation et la biodéposition. Océanis 13, 531-541.

Turpin, V., Robert, J.M., 1998. Fertilité potentielle des eaux des claires ostréicoles de la région de Marennes - Oléron pour Haslea ostrearia Simonsen, en période d'affinage des huîtres. In: Hussenot J., Buchet V. (Eds), Marais maritimes et aquaculture. Actes colloq. Ifremer 19, Brest, 97-106.

Turpin, V., Robert, J.M., Goulletquer, P., 1999. Limiting nutrients of oyster ponds seawater in the Bay of Marennes Oléron region for Haslea ostrearia (Simonsen): application to the mass production of the diatom in mesocosm experiments. Aquatic Liv. Res. 12(5), 335-342.

Turpin, V., 1999. Etude des évènements physico-chimiques et biologiques présidant à la prolifération d'Haslea ostrearia (Simonsen) dans les claires ostréicoles de la région de Marennes - Oléron : implication dans la maîtrise du verdissement. Thèse de l'Université de Nantes, pp 208.

Vincendeau, M.L., 1987. Etude expérimentale de la fertilité des eaux des milieux 
conchylicoles : influence de l'excrétion des huîtres et des palourdes sur la production des diatomées dominantes. Thèse de Doctorat de l'Université Paris 6 Spécialité : Algologie. pp 223.

Zanette, Y., Garnier, J., 1981. Etude préliminaire de l'impact des huîtres Crassostrea gigas Thunberg en élevage sur la biomasse des microorganismes des claires de Marennes - Oléron. Cons. Inter. Expl. Mer, C.M. - L : 14pp. 